\title{
Household Income Based on a Broad View of Production*
}

\author{
Mitsuhiko Iyoda \\ Momoyama Gakuin University, Osaka, Japan
}

\begin{abstract}
This paper considers the real value of unpaid work. Actual living satisfaction depends not only on market income measured using the current concept of GDP, but also on unpaid household production. We try to estimate broad household income in Japan based on 2011 government estimates. We assume three household life stages, each of which consists of three cases categorized by the spouse's type of work. The results show that income differences between the three cases were very small and women worked longer hours than men in all household life stages. This reveals a different possible view of income distribution and poverty, in which women are overburdened.
\end{abstract}

Keywords: income distribution, unpaid household production, household life stages, overburdened women

\section{Introduction}

This paper considers the real value of unpaid work. Ordinary living standards are measured by market income. However, our actual living satisfaction depends not only on market income based on the current concept of GDP, but also on unpaid household production. Taking household production into consideration renders a different view of income distribution and poverty.

Housekeeping, child-rearing, nursing care, volunteer activities, etc., are included in unpaid work, which is defined as productive activities that can be replaced by a third party and that are carried out in the market (Hill, 1979). These activities are excluded in Japan's current national accounts (SNA). They are, however, estimated for some countries in satellite accounts that are comparable to GDP, mostly countries in Europe or North America. The Economic Planning Agency in Japan has estimated unpaid work every five years since 1992 based on Japan's GDP starting in 1981. The Agency estimates housekeeping, nursing care, child-rearing, shopping, and social activities. ${ }^{1}$

Japan is an aging society with a very low birthrate of 1.43 (the total fertility rate in 2013). The author has dealt with this theme elsewhere. ${ }^{2}$ The population has been decreasing since 2007 (in terms of natural change). In Japan, after having a baby, about $60 \%$ of married women quit their jobs. ${ }^{3}$ Dealing with household production based on a broader view than the current GDP will reveal a more realistic view of households' circumstances than the current method. Family behavior may offer some hints in this regard. We examine three

\footnotetext{
* Acknowledgement: This is a revised version of a paper having the same title presented at the JEPA (Japan Economic Policy Association) General Meeting held on May 30-31, 2015. The author received valuable suggestions from discussant Prof. W. Chida (Meiji University), some of which are mentioned in the course of this paper. The paper was presented at the 34th IARIW General Conference (Session 4A: Household Accounts, Dresden, Germany, 2016). The author also received valuable comments. Mitsuhiko Iyoda, Professor Emeritus, Momoyama Gakuin University. Email: m-iyoda@andrew.ac.jp.

1 See Department of National Accounts (DNA) of the Economic and Social Research Institute (ESRI), Cabinet Office, Government of Japan (CAO of GoJ, 2013) (hereafter shortened to DNA, 2013) for the most recent estimate.

2 Iyoda (2013) tried to explain the problems that arise in Japanese society and discussed a way toward a solution.

$370.7 \%$ of childless married women work, among which $62.1 \%$ quit their jobs after having their first child (2005-2009 average) (21 Seiki Shokugyo Zaidan, 2012, Fig-Table 2-2-5).
} 
household life stages (hereafter shortened to household stages) in 5-year age brackets for married women, each of which is sub-classified by the spouse's type of work.

Stiglitz, Sen, and Fitoussi (2009, p. 51) showed that household production amounts to about 35\% of conventionally measured GDP in France, about 40\% in Finland, and 30\% in the United States (1995-2006 average). According to the DNA (2013) estimate (Chart-Table 1), the total unpaid value in Japan was $29.4 \%$ of its GDP in 2011 (estimated by the opportunity cost method).

As an economy develops, more women go to work and household production is replaced by third parties, carried out in the market. Per capita GDP increases, but in a broader sense income does not increase as much, because the value of the woman's unpaid work may not be completely replaced. ${ }^{4}$ Conventionally measured income is not able to capture all the production involved when analyzing such situations.

\section{Methodology and Framework}

\section{Method of Monetary Estimate}

The monetary value of unpaid work is estimated as: annual per capita unpaid work hours $\times$ wage rate (per hour) $\times$ number of persons. Therefore, the monetary value of unpaid work depends on the hourly wage rate. DNA (2013) estimated the monetary value of unpaid work using the following three methods:

(1) Opportunity cost method: Unpaid work is estimated by the benefits that could have been obtained by choosing the best alternative opportunity. Its monetary value reflects not the content of unpaid work but who does it. For an estimate, they use "average scheduled wages by occupation" by sex and age bracket (Statistics and Information Department of the Ministry of Health, Labour and Welfare [SID of MHLW], 2013). Using this method, different wage rates are applied to estimates for different age brackets. That this method does not take into account what kind of unpaid work is done but who does it and at what age is very important;

(2) Replacement cost method - specialist approach: Unpaid work is estimated using the wage rates of specialists engaged in similar services (Ibid.). In this method, different wage rates are applied based on the kind of unpaid work, irrespective of the worker's age;

(3) Replacement cost method - generalized approach: Unpaid work is estimated using the wage rates of household employees so that differences in age and type of unpaid work are not taken into consideration. ${ }^{5}$

Fortunately, as mentioned above, we have had a government estimate of unpaid work once every five years since 1981. According to the government estimate, the household production (value of unpaid work) to GDP ratio of 2011 is $29.4 \%$ based on Method 1, 23.0\% based on Method 2, and 20.7\% based on Method 3. These percentages were 20.4\%, 20.1\%, and 14.3\%, respectively, in 1981 (DNA, 2013, Figure-Table 1). Method 1 produces the highest percentage, followed by Method 2 and then Method 3. The percentage differences reflect differences in wage rates applied in calculating the value of unpaid work. Using the government estimate based on opportunity cost (Method 1), we estimate the value of household production at different household stages for three cases.

\footnotetext{
${ }^{4}$ Replaced household production may increase income under the GDP concept and the value of that increase may theoretically be greater than the replaced value. This is because household production may be partly replaced by the introduction of housework-related electric appliances and/or using market services supplied at low cost, not to mention business profits being included in the market value. However, the actual results depend on the true change in unpaid work hours. We discuss this matter in Section 4.

${ }_{5}^{5}$ Time-use data for these three methods were obtained from the Statistics Bureau of the Ministry of Internal Affairs and Communications (SB of MIAC, 2013).
} 
The reason why we use the opportunity cost method is that we use wage rates that vary by sex and age bracket. The household burden varies greatly by age bracket (i.e., household stage), particularly for married women. Part of our intention in this paper is to explain the real household burdens of men and women. In this respect, dealing with this matter in terms of average results does not clarify specific conditions particularly well.

\section{Framework}

Household stages and common assumptions. We use three household stages corresponding to 5-year age brackets for married women, each divided into three cases by the type of work done by the woman (see Table 1):

Table 1

Summary of Japanese Household Annual Income by Household Stage (2011)

\begin{tabular}{|c|c|c|c|c|}
\hline & & Stage I & Stage II & Stage III \\
\hline \multicolumn{2}{|c|}{$\begin{array}{l}\text { Household Size } \\
\text { Couple (children) }\end{array}$} & $2(1.36)$ & $2(1.87)$ & $2(2.01)$ \\
\hline \multicolumn{2}{|c|}{ Age (married women) } & $30-34$ & $40-44$ & $50-54$ \\
\hline \multirow{3}{*}{ Income $^{2)}$} & (1) $\mathrm{HOH}^{*}$ & A (4.40), B and C (4.60) & A (5.79), B and C (5.99) & A (6.48), B and C (6.68) \\
\hline & (2) Working spouses & $\begin{array}{l}\text { Full }(3.63)(\mathrm{HOH} \times 82.3 \%) \\
\text { Part (1.03) }\end{array}$ & $\begin{array}{l}\text { Full }(3.95)(\mathrm{HOH} \times 67.3 \%) \\
\text { Part }(1.03)\end{array}$ & $\begin{array}{l}\text { Full }(3.87)(\mathrm{HOH} \times 58.1 \%) \\
\text { Part }(1.03)\end{array}$ \\
\hline & (3) Non-working spouses & None (0) & None (0) & None (0) \\
\hline \multirow[t]{3}{*}{$\begin{array}{l}\text { Household } \\
\text { production }^{3)}\end{array}$} & $\begin{array}{l}\text { (1) Working } \\
\text { (married women) }\end{array}$ & $\begin{array}{l}\text { Working average (2.47) } \\
(56.9 \% \text { of level produced } \\
\text { by non-working women) } \\
\text { Full }(2.16)(49.8 \%) \\
\text { Part }(2.78)(64.0 \%)^{4)}\end{array}$ & $\begin{array}{l}\text { Working average (2.68) } \\
\text { (62.1\% of level produced } \\
\text { by non-working women) } \\
\text { Full }(2.28)(52.7 \%) \\
\text { Part }(3.03)(70.2 \%)^{4)}\end{array}$ & $\begin{array}{l}\text { Working average (2.19) } \\
(60.5 \% \text { of level produced } \\
\text { by non-working women) } \\
\text { Full }(1.87)(51.4 \%) \\
\text { Part }(2.40)(66.0 \%)^{4)}\end{array}$ \\
\hline & $\begin{array}{l}\text { (2) Non-working } \\
\text { (married women) }\end{array}$ & (4.34) (100\%) & (4.32) (100\%) & (3.63) (100\%) \\
\hline & (1) Working (married men) & $(0.61)$ & $(0.54)$ & $(0.50)$ \\
\hline
\end{tabular}

Notes. Monetary units are in million yen. ${ }^{*}: \mathrm{HOH}$ denotes head of household. Sources: ${ }^{1)}$ : Numbers in parentheses are average numbers of children by stage, except for Stage III (50-54), which uses the average number for female spouses in age bracket (45-49) (National Institute of Population and Social Security Research [NIPSSR], 2015, Table 4-25); ${ }^{2}$ : Total cash earnings of establishments with 10 employees or more are calculated as: contractual cash earnings $\times 12+$ annual special cash earnings (Vol. 1, Table 2, SID of MHLW, 2013). Data are whole - private and public enterprises - industries excluding agriculture, fishing and forestry. The same age bracket with spouses is applied to $\mathrm{HOHs}$; ${ }^{3 \text { ) }}$ DNA (2013), Figure-Table 13 for household products for married women (working average and non-working) and married men (working); and ${ }^{4}$ : See Appendix A for the full- and part-time estimates.

(1) Stages: (I) couples with 1.36 children in the 30-34 age bracket; (II) couples with 1.87 children in the 40-44 age bracket; and (III) couples with 2.01 children in the 50-54 age bracket (Numbers of children are the average values by stage);

(2) Cases: (A) the head of household ( $\mathrm{HOH}$ ) and spouse both work full-time; (B) the $\mathrm{HOH}$ works full-time and the spouse works part-time; and (C) the $\mathrm{HOH}$ works full-time and the spouse is not working (doing housework);

(3) Income: The Japanese income tax system allows a household head to receive a dependant (spouse) allowance if the spouse's income does not exceed 1.03 million yen. For household heads in cases A, B, and C (the same basic amount based on the survey), survey data show spousal allowances by household heads' workplaces (about 0.2 million yen per year ${ }^{6}$ ). This is deducted for household heads in case A. Spousal earnings: case A, based on the survey; case B, 1.03 million yen per year; and case C, no income (SID of MHLW, 2013, Table 2; monetary units are in million yen ${ }^{7}$ );

\footnotetext{
6 203,000 yen (16,900 per month, survey industry average in 2012) (Central Labour Relations Commission, 2014).

7 Yen converted to US dollars using a PPP (purchasing power parity) value of 107.454 yen per US dollar (2011). Retrieved from OECD, StatExtracts (http://stats.oecd.org/Index.aspx?DataSetCode=SNA_Table4\#).
} 
(4) Household production: Consideration of married women's (spouses) and men’s (HOH) unpaid work (housekeeping, child-rearing, nursing care, shopping, and social activities ${ }^{8}$ ).

\section{Income}

\section{Income by Stage}

The incomes of Stage I couples are as follows: $\mathrm{HOH} \mathrm{A}=4.40$ million yen, and $\mathrm{HOHs} \mathrm{B}$ and $\mathrm{C}=4.60$ million yen; and spouses $\mathrm{A}=3.63$ million yen, $\mathrm{B}=1.03$ million yen, and $\mathrm{C}=0 .{ }^{9}$

The average unpaid value of the work done by spouses in cases A and B is 2.47 million yen, which amounts to $56.9 \%$ of that done by non-working homemakers, which is 4.34 million yen. We have no precise data to show the difference between unpaid work done by women in cases A and B. Based on the 1990 data, ${ }^{10}$ we estimate that full-time working spouses do $49.8 \%$ of the unpaid work of non-working spouses and part-time workers do $64.0 \%$ (see Appendix A). The unpaid value for work done by HOHs in cases A, B, and C is 0.61 million yen.

As the opportunity cost of household work, DNA (2013) used the wage rate obtained as [scheduled cash earnings/actual numbers of scheduled hours worked] by sex and age (both numerator and denominator are monthly averages over all sizes of enterprise). ${ }^{11}$

Table 2

Household Income Based on a Broader View (2011) (Units: Million Yen/Year)

\begin{tabular}{|c|c|c|c|c|c|c|c|c|c|c|}
\hline \multicolumn{3}{|c|}{ Household } & \multicolumn{4}{|c|}{ Annual market income } & \multicolumn{2}{|c|}{$\begin{array}{c}\text { Household } \\
\text { production value }^{4)}\end{array}$} & \multicolumn{2}{|c|}{ Total income } \\
\hline Stage & Case & $\operatorname{Size}^{1)}$ & $\mathrm{HOH}^{2)}$ & Spouse & Subtotal & (\%) & Spouse (\%) & $\mathrm{HOH}$ & $\begin{array}{l}\text { Grand } \\
\text { total }^{3)}\end{array}$ & $(\%)$ \\
\hline I & A & $\begin{array}{l}2 \\
(1.36)\end{array}$ & 4.40 & 3.63 & $\begin{array}{c}8.02 \\
(4.23)\end{array}$ & (100\%) & $\begin{array}{c}2.16 \\
(49.8 \%)\end{array}$ & 0.61 & $\begin{array}{l}10.79 \\
(5.69)\end{array}$ & $(100 \%)$ \\
\hline I & B & $\begin{array}{l}2 \\
(1.36)\end{array}$ & 4.60 & 1.03 & $\begin{array}{c}5.63 \\
(2.86)\end{array}$ & (70\%) & $\begin{array}{c}2.78 \\
(64.0 \%)\end{array}$ & 0.61 & $\begin{array}{c}9.02 \\
(4.58)\end{array}$ & (84\%) \\
\hline I & $\mathrm{C}$ & $\begin{array}{c}2 \\
(1.36) \\
\end{array}$ & 4.60 & 0 & $\begin{array}{c}4.60 \\
(2.30)\end{array}$ & (57\%) & $\begin{array}{r}4.34 \\
(100 \%)\end{array}$ & 0.61 & $\begin{array}{c}9.55 \\
(4.77)\end{array}$ & (88\%) \\
\hline II & A & $\begin{array}{c}2 \\
(1.87)\end{array}$ & 5.79 & 3.95 & $\begin{array}{c}9.74 \\
(5.13)\end{array}$ & $(100 \%)$ & $\begin{array}{c}2.28 \\
(52.7 \%)\end{array}$ & 0.54 & $\begin{array}{l}12.56 \\
(6.62)\end{array}$ & $(100 \%)$ \\
\hline II & B & $\begin{array}{c}2 \\
(1.87) \\
\end{array}$ & 5.99 & 1.03 & $\begin{array}{c}7.02 \\
(3.57)\end{array}$ & $(72 \%)$ & $\begin{array}{c}3.03 \\
(70.2 \%)\end{array}$ & 0.54 & $\begin{array}{l}10.59 \\
(5.38)\end{array}$ & $(84 \%)$ \\
\hline II & $\mathrm{C}$ & $\begin{array}{l}2 \\
(1.87)\end{array}$ & 5.99 & 0 & $\begin{array}{c}5.99 \\
(2.99)\end{array}$ & (62\%) & $\begin{array}{r}4.32 \\
(100 \%)\end{array}$ & 0.54 & $\begin{array}{l}10.85 \\
(5.42)\end{array}$ & (86\%) \\
\hline III & A & $\begin{array}{c}2 \\
(2.01) \\
\end{array}$ & 6.48 & 3.87 & $\begin{array}{l}10.36 \\
(5.46)\end{array}$ & (100\%) & $\begin{array}{c}1.87 \\
(51.4 \%) \\
\end{array}$ & 0.50 & $\begin{array}{l}12.73 \\
(6.71)\end{array}$ & $(100 \%)$ \\
\hline III & B & $\begin{array}{l}2 \\
(2.01)\end{array}$ & 6.68 & 1.03 & $\begin{array}{c}7.71 \\
(3.92)\end{array}$ & $(75 \%)$ & $\begin{array}{c}2.40 \\
(66.0 \%)\end{array}$ & 0.50 & $\begin{array}{l}10.61 \\
(5.40)\end{array}$ & $(83 \%)$ \\
\hline III & $\mathrm{C}$ & $\begin{array}{l}2 \\
(2.01)\end{array}$ & 6.68 & 0 & $\begin{array}{c}6.68 \\
(3.34)\end{array}$ & $(65 \%)$ & $\begin{array}{r}3.63 \\
(100 \%)\end{array}$ & 0.50 & $\begin{array}{l}10.81 \\
(5.40)\end{array}$ & (85\%) \\
\hline
\end{tabular}

Notes. ${ }^{1)}$ : Couple and children in parentheses; ${ }^{2}$ : HOH denotes head of household; ${ }^{3)}$ : Equivalence-based income in parentheses, which is calculated by dividing household income by the square root of household size (a couple plus the number of children assumed in parentheses); and ${ }^{4)}$ : Same as the "household production” row of Table 1.

\footnotetext{
${ }^{8}$ Social activities are not always beneficial for the activity performer's family, but for others. However, social activities are only a small percentage of all unpaid hours in Japan (3.2\% in 2011, DNA, 2013, Fig-Table 3).

${ }_{9} \mathrm{HOH}$ incomes are for men in the same age bracket as their spouses.

${ }^{10}$ See Nippon Hoso Kyokai (NHK) Department of Public Opinion Survey (DPOS, 1992), Figure-Tables III-13 and III-14. These data meet our analytical needs. The dataset includes time-use data by spouse's type of work (full-time, part-time, or homemaker). The data are old, but we use the data in ratio form, assuming the same ratios as in 1990 are appropriate for 2011.

${ }^{11}$ These opportunity costs are: Stages I (M 1,663, F 1,430), II (M 2,204, F 1,559), and III (M 2,502, F 1,536) (wage rates calculated in terms of yen from SID of MHLW, 2013, Vol. 1, Table 1 or obtained from DNA, 2013, p. 11).
} 
Table 2 presents estimates of household income in the broader sense for Stages I, II, and III for each case. The income for case A of Stage I households, which have a market income of 8.02 million yen, is taken as a benchmark (100\%). Case B has a market income of 5.63 million yen (70\%), and case C couples earn 4.60 million yen (57\%). However, when household production is included, the incomes total 10.79 million yen for case A (again taken as a benchmark, 100\%), 9.02 million yen for case B (84\%), and 9.55 million yen for case C (88\%). The initial differences between cases A, B, and C are very large. After considering the value of unpaid work, the gaps narrow, with case $\mathrm{C}$ showing the most difference. The results for Stages II and III are similar.

Table 3 shows household income by sex based on a broader view of production. Because of large wage differences, the annual market income of women is small. If household production is included, the differences shrink. Of particular note is that the combined value produced by women working full-time exceeds that of the $\mathrm{HOH}$ in Stage I. As they move into later stages, the ratio of spouse/HOH income decreases, reflecting how Japan's wage structure differs for men and women.

Table 3

Broad-Based Household Income by Sex (2011) (Units: Million Yen/Year or \%)

\begin{tabular}{|c|c|c|c|c|c|c|c|c|c|c|}
\hline \multicolumn{3}{|c|}{ Household } & \multicolumn{3}{|c|}{ Annual market income } & \multicolumn{2}{|c|}{$\begin{array}{c}\text { Household } \\
\text { production value }\end{array}$} & \multicolumn{3}{|c|}{ Total income } \\
\hline Stage & Case & Size & $\begin{array}{l}\text { Male } \\
\mathrm{HOH}\end{array}$ & $\begin{array}{l}\text { Female } \\
\text { spouse }\end{array}$ & $\begin{array}{l}\text { Spouse/HOH } \\
\text { ratio (\%) }\end{array}$ & $\begin{array}{l}\text { Female } \\
\text { spouse }\end{array}$ & $\begin{array}{l}\text { Male } \\
\mathrm{HOH}\end{array}$ & $\mathrm{HOH}$ & Spouse & $\begin{array}{l}\text { Spouse/HOH } \\
\text { ratio (\%) }\end{array}$ \\
\hline I & $\mathrm{A}$ & $2(1.36)$ & 4.40 & 3.63 & $(82.5)$ & 2.16 & 0.61 & 5.01 & 5.79 & $(115.6)$ \\
\hline I & $\mathrm{B}$ & $2(1.36)$ & 4.60 & 1.03 & $(22.4)$ & 2.78 & 0.61 & 5.21 & 3.81 & $(73.2)$ \\
\hline I & $\mathrm{C}$ & $2(1.36)$ & 4.60 & 0 & $(0)$ & 4.34 & 0.61 & 5.21 & 4.34 & (83.4) \\
\hline II & $\mathrm{A}$ & $2(1.87)$ & 5.79 & 3.95 & $(68.2)$ & 2.28 & 0.54 & 6.33 & 6.23 & (98.4) \\
\hline II & B & $2(1.87)$ & 5.99 & 1.03 & $(17.2)$ & 3.03 & 0.54 & 6.53 & 4.06 & $(62.2)$ \\
\hline II & $\mathrm{C}$ & $2(1.87)$ & 5.99 & 0 & $(0)$ & 4.32 & 0.54 & 6.53 & 4.32 & $(66.2)$ \\
\hline III & $\mathrm{A}$ & $2(2.01)$ & 6.48 & 3.87 & $(59.8)$ & 1.87 & 0.50 & 6.98 & 5.74 & (82.3) \\
\hline III & B & $2(2.01)$ & 6.68 & 1.03 & (15.4) & 2.40 & 0.50 & 7.18 & 3.43 & $(47.8)$ \\
\hline III & $\mathrm{C}$ & $2(2.01)$ & 6.68 & 0 & (0) & 3.63 & 0.50 & 7.18 & 3.63 & (50.5) \\
\hline
\end{tabular}

Note. Based on Table 2, this table shows spouse and $\mathrm{HOH}$ incomes and the spouse/HOH income ratios (\%).

Table 4

Wage Rate Differences by Sex and Type of Work (2011) (Units: Yen/Hour or \%)

\begin{tabular}{|c|c|c|c|c|c|c|c|c|c|}
\hline \multirow{2}{*}{\multicolumn{2}{|c|}{ Household }} & \multirow{2}{*}{\multicolumn{2}{|c|}{$\begin{array}{c}\text { Full-time }^{1)} \\
\text { Hourly wage rate }\end{array}$}} & \multirow{3}{*}{$\begin{array}{l}\text { Ratio (\%) } \\
\text { Female/Male }\end{array}$} & \multirow{2}{*}{\multicolumn{2}{|c|}{$\begin{array}{c}\text { Part-time } \\
\text { Hourly wage rate }\end{array}$}} & \multirow{3}{*}{$\begin{array}{l}\text { Ratio (\%) } \\
\text { Female/Male }\end{array}$} & \multirow{2}{*}{\multicolumn{2}{|c|}{$\begin{array}{c}\text { Part/Full-time } \\
\text { Wage ratio (\%) }\end{array}$}} \\
\hline & & & & & & & & & \\
\hline Stage & Age & Male & Female & & Male & Female & & Male & Female \\
\hline $\mathrm{I}$ & $30-34$ & 2,055 & 1,731 & 84.2 & 1,137 & 1,046 & 92.0 & 55.3 & 60.4 \\
\hline II & $40-44$ & 2,776 & 1,912 & 68.9 & 1,188 & 1,018 & 85.7 & 42.8 & 53.2 \\
\hline III & $50-54$ & 3,174 & 1,879 & 59.2 & 1,185 & 993 & 83.8 & 37.3 & 52.8 \\
\hline
\end{tabular}

Notes. ${ }^{1)}$ : Full-time hourly wage rates were calculated by dividing incomes (HOH and spouse) in Table 1 (minus overtime allowance) by scheduled (work) hours in Table 5. Source: SID of MHLW (2013), Vol. 3, Table 13 for part-time hourly wage rates (http//:www.mhlw.go.jp/tokei/itiran/roudou/chingin/kouzou/z2011).

Table 4 clarifies wage rate differences by sex and type of work based on Wage Census (Basic Survey on Wage Structure ${ }^{12}$ ) data. We observe that full-time wage rate differences between men and women are large. In the later stages, the differences widen from $84.2 \%$ to $68.9 \%$, then $59.2 \%$. The story is similar for part-time

\footnotetext{
${ }^{12}$ My previous estimate had been based on MLS data (SID of MS, MHLW, 2013), but Prof. Chida suggested my using Wage Census data (see Section Work Hours for work hours data).
} 
wage differences. More importantly, though these are rough estimates, wages for full-time men and women are very different from part-time wages. For men, part-time wages go from $55.3 \%$ to $42.8 \%$, then $37.3 \%$ of full-time wages in Stages I, II, and III, respectively. For women, these percentages are $60.4 \%$, 53.2\%, and $52.8 \%$, respectively.

To learn the possibility of using other survey data for the household stage, we examined two classifications: (1) stage by age bracket; and (2) child-rearing stage by youngest child $^{13}$, in Appendix B. As a result, we judge that child-rearing stage by youngest child cannot be used as a proxy variable of age bracket stage in our present approach (see Appendix B for further details).

\section{The Effect of Considering Household Production on Income Distribution}

Table 2 also shows the household income differences for both conventional market income and more broadly defined income. Considering the unpaid value of work, household income differences between the cases universally decreased. However, case $\mathrm{C}$, in which the $\mathrm{HOH}$ works full-time and the female spouse is not working, shows a greater increase in income by using the broad definition than do cases $\mathrm{A}$ and $\mathrm{B}$. The household income gap by age also decreases by 8-14 percentage points for case B and 20-31 percentage points for case C. Considering the unpaid work, full-time working female spouses produce more than full-time male household heads in Stage I. This agrees with Hamada's (2006, pp. 12-13) estimate that the gap in the value of unpaid work among income brackets is very small. ${ }^{14}$ In income flow terms only, households in case A would have higher living standards than those in case C. However, from a broad consumption viewpoint that includes non-market household production, the conventional judgment on living standards may not apply. As we see in Table 2, a different view of income distribution can emerge.

This equalizing effect on income distribution may also lead to a decrease in the conventionally measured poverty rate. ${ }^{15}$ A different view of the poverty rate may emerge as well.

\section{Work Hours}

We have computed broad income estimates that include the value of unpaid work. We have shown that wage differences between men and women are large in Japan. Here, we estimate the work hours of household heads and spouses.

We have two data sources for work hours: Wage Census and MLS (Monthly Labour Survey). Wage Census data include work hours for regular employees of establishments with 10 employees or more, which are divided into general workers and part-timers. For both general workers and part-timers, work hours by sex and age are available. MLS includes work hours for regular employees of establishments with five employees or more. The MLS data are also divided into general workers and part-timers; however, no data by age and sex are available for the employees covered by MLS, so this data source is not sufficient for the needs of the present study.

\footnotetext{
${ }^{13}$ At Prof. Chida's suggestion, the possibility of using child-rearing stage by youngest child as a proxy variable is examined in Appendix B.

${ }^{14}$ Hamada (2006) dealt with the monetary value of unpaid work as separate income and compared it with conventional household income. He found that unpaid values are similar among conventional household income brackets. As a result, the pseudo Gini coefficients for unpaid household value were very low at 0.1064 (0.3578) for all households and 0.0096 (0.3050) for households with two or more members for 2001. In parentheses are the Gini coefficients of annual household income derived using Statistics Bureau of the Ministry of Public Management, Home Affairs, Post and Telecommunications (SB of MPHPT, 2001; 2002). The value of unpaid work for conventional household income was 0.452 for all households and 0.479 for those with two or more members (Tables 4(1), 6(1), and 6(2) based on the opportunity cost).

${ }_{15}$ The poverty level is conventionally defined as income less than half of the adjusted median income. The adjusted income here means an equivalence-based income, specifically that calculated by dividing household income by the square root of household size.
} 
Table 5 summarizes the work hours of HOHs and spouses by work type. This table shows two kinds of work hours: (1) scheduled hours (worked); and (2) total hours (worked). The difference between (1) and (2) is whether they include overtime. Scheduled hours (1) for HOHs and spouses (both working full-time) do not differ by stage except for spouses in Stage III, which are slightly more. For spouse part-timers, the work hours differ somewhat by age. Total hours (2) for full-time HOHs and spouses differ most by stage. We use the same hours for spouse part-timers in (1) and (2), since we do not have overtime data for this category, but assume the amount of overtime to be small. Including unpaid work hours, women work more hours than men do in all household stages. Full-time working women exceed three thousand hours per year in all household stages, as do non-working homemakers in Stage I. Women working part-time also exceed three thousand hours in household Stages I and II. In these cases, work hour differences between men and women are great.

Table 5

Summary Table of Work Hours of HOHs and Spouses by Work Type (2011)

\begin{tabular}{|c|c|c|c|c|c|c|}
\hline \multirow[t]{2}{*}{ Case } & \multicolumn{2}{|c|}{$\begin{array}{c}\text { Stage I: } 2 \text { (1.36), (30-34) } \\
\text { Annual work hours } \\
\text { Paid hours (Unpaid hours) }{ }^{1)}\end{array}$} & \multicolumn{2}{|c|}{$\begin{array}{c}\text { Stage II: } 2 \text { (1.87), (40-44) } \\
\text { Annual work hours } \\
\text { Paid hours (Unpaid hours) }^{1)}\end{array}$} & \multicolumn{2}{|c|}{$\begin{array}{c}\text { Stage III: } 2 \text { (2.01), (50-54) } \\
\text { Annual work hours } \\
\text { Paid hours (Unpaid hours) }^{1)}\end{array}$} \\
\hline & $\overline{\mathrm{HOH}^{2)}}$ & Spouse & $\overline{\mathrm{HOH}}$ & Spouse & $\overline{\mathrm{HOH}}$ & Spouse \\
\hline \multicolumn{7}{|c|}{ (1) Scheduled hours } \\
\hline A & 2,004 & 1,956 & 2,004 & 1,956 & 2,004 & 1,968 \\
\hline B & 2,004 & 1,156 & 2,004 & 1,138 & 2,004 & 1,178 \\
\hline $\mathrm{C}$ & 2,004 & 0 & 2,004 & 0 & 2,004 & 0 \\
\hline \multicolumn{7}{|c|}{ (2) Total hours } \\
\hline A & $2,232(367)$ & $2,076(1,511)$ & $2,184(246)$ & $2,054(1,461)$ & $2,136(198)$ & $2,040(1,214)$ \\
\hline$B^{3)}$ & $2,232(367)$ & $1,156(1,942)$ & $2,184(246)$ & $1,138(1,946)$ & 2,136 (198) & $1,178(1,559)$ \\
\hline $\mathrm{C}$ & $2,232(367)$ & $0(3,035)$ & $2,184(246)$ & $0(2,772)$ & $2,136(198)$ & $0(2,362)$ \\
\hline
\end{tabular}

Notes. ${ }^{1)}$ : Unpaid work hours are in parentheses. The author estimated unpaid work hours for spouses in cases $\mathrm{A}$ and $\mathrm{B}$ (see Appendix A); ${ }^{2)}$ : HOH denotes head of household; ${ }^{3)}$ : The same work hours of part-time spouses are used as those in (1). Sources: SID of MHLW (2013, pp. 98-101), Vol. 1, Table 1, for general workers; Vol. 3, Table 13 for part-timers (establishments with 10 employees or more, all industries covered); DNA (2013), Figure-Table 14 for unpaid work hours of non-working spouses and HOHs.

In Table 5, we simply assumed that HOH's unpaid work hours are the same in all three cases (A, B, and C) because data broken down with respect to our household stages were not obtained. However, data on a related characteristic were obtained and were used to create Table $6 .{ }^{16}$ As shown, statistics for child-rearing stages by youngest child suggest that HOH's unpaid work hours are different according to whether the female spouse is working or not. Furthermore, the ratio of unpaid work hours of working spouse households to non-working spouse households is greater than that of our classification by female spouse's age. This ratio as a percentage is 57.0 for Stage I (see Table B1 in Appendix B). Table 6 shows values 74.6 (youngest child less than three) and 69.2 (youngest child less than six), neither of which precisely corresponds to Stage I. Our classification by age includes no-child households, but child-rearing classification by youngest child does not include such cases.

As explained at the end of Section 3.1 (Income by Stage) and in Appendix B, however, the child-rearing stage by youngest child does not correspond to the household stage classification by age, particularly in the first stage (as just described above). Specifically, there exist categorical differences, so it is difficult to adopt the child-rearing stage classification when using our current approach.

${ }^{16}$ Prof. Chida suggested clarifying differences by using child-rearing classification data. 
Table 6

Unpaid Work Hours by Work Type and Child-Rearing Stage (by Youngest Child) (Units: Annual Hours; Weekly Average Minutes in Parentheses)

\begin{tabular}{|c|c|c|c|c|c|c|}
\hline \multirow{3}{*}{$\begin{array}{l}\text { Youngest child } \\
\text { (years old) }\end{array}$} & \multicolumn{3}{|c|}{$\mathrm{HOH}$} & \multicolumn{3}{|c|}{ Spouse } \\
\hline & (1) $\mathrm{HOH}(\mathrm{W})$ & (2) $\mathrm{HOH}(\mathrm{W})$ & $(1) /(2)$ & (1) $\mathrm{HOH}(\mathrm{W})$ & (2) $\mathrm{HOH}(\mathrm{W})$ & $(1) /(2)$ \\
\hline & Spouse (W) & Spouse (Non-w) & $(\%)$ & Spouse (W) & Spouse (Non-w) & (\%) \\
\hline Less than 3 & 572 (94) & $462(76)$ & 123.7 & $2,573(423)$ & 3,449 (567) & 74.6 \\
\hline Less than 6 & 444 (73) & $414(68)$ & 107.4 & $2,257(371)$ & 3,261 (536) & 69.2 \\
\hline $6-9$ & $256(42)$ & 219 (36) & 116.7 & 1,855 (305) & 2,658 (437) & 69.8 \\
\hline $10-14$ & $189(31)$ & $189(31)$ & 0.0 & $1,740(286)$ & 2,731 (449) & 63.7 \\
\hline More than 15 & $183(30)$ & $213(35)$ & 85.7 & $1,570(258)$ & 2,373 (390) & 66.2 \\
\hline
\end{tabular}

\section{Summary Comments}

\section{Incomes and Work Hours}

A household in Stage I is a married couple with 1.36 children who are typically nursery or kindergarten age (not yet in school). Stage II households are married couples with 1.87 children mostly supposed to be in primary or junior high school. Household Stage III couples are older with 2.01 children mostly supposed to be of senior high school and college age (see Tables 2 and 3).

Considering unpaid work, married women working full-time earn more than the HOHs (husbands) in Stage I. In all other cases, men's incomes are greater than women's are. However, we cannot estimate women's real effort because wage rates for men and women are very different in Japan (see Table 3 for the spouse/HOH income ratio; Table 4). In viewing the work hours of HOHs and spouses by work type, women work longer hours than men do in all household stages (see Table 5). The annual work hours of full-time working women exceed three thousand hours in all household stages, as do those for non-working homemakers in Stage I. Women working part-time also exceed three thousand work hours per year in Stages I and II. In these cases, there are large differences in the hours worked by men and women. Japanese working women are overloaded, especially married women employed full-time, who work about half the hours of a non-working homemaker after their outside work hours (see Table 5). Japanese married men are not so cooperative with housework, but they also have long work hours, and typically have long commute times as well. These facts are likely part of the background conditions that have resulted in Japan's low birthrate, in that people may seem too busy to keep a desirable work/life balance.

Data: Our estimates are mostly based on surveys from 2011. We have the value of unpaid work done by working spouses, but do not have that value decomposed into full- and part-time workers. We also lack recent time-use data for unpaid work. We estimated each of the unpaid work values using 1990 data for 10-year age brackets (30s, 40s, and 50s).

The data are old, but we do not believe using them will unacceptably distort the results. With the growing tendency for later marriage during the decades since 1990, the peak years of unpaid work are occurring later in women's lives. In 1990, women and men first married at average ages of 25.9 and 28.4 years, respectively, increasing to 29.0 and 30.7 years in 2011 (NIPSSR, 2015, Table 6-12). For our estimates, we calculated unpaid work time not in absolute but in relative terms, using a full-time/part-time ratio. Data for 5-year age brackets 
were not available for 1990, so we used 10-year age brackets for 1990 as proxies for 5-year age brackets in 2011. For example, data for women in their 30s for 1990 are used as the basis for the 30-34 year age bracket for 2011. Our results depend on these treatments, which may be a weakness in the estimates. This, however, is limited to the decomposition of the value of unpaid work by female spouses into full- and part-time ranges.

\section{Household Production to GDP Ratio}

According to Hill's (1979) definition, household production can be replaced by third parties and carried out in the market. The value of unpaid work compared to the GDP may decrease in the long run. Talberth, Cobb, and Slattery (2007) showed that the ratio of non-market products and services to GDP personal consumption was $65 \%$ in 1950, decreasing to $33 \%$ in 2004 in the United States.

Since the first estimate for 1981, the ratio of the value of unpaid work to the GDP in Japan has been increasing for all three calculation methods (see Section 2.1: Method of Monetary Estimate). Hamada (2006, p. 8) raised two factors in this connection: the growth of the population 15 years old and over and GDP growth. Population growth itself has not been large but its structure changed dramatically during the period from 1981 to 2011. The aging of the baby boom population born from 1947 to 1949 caused this. Its aging has had a great effect on the number of births, the total value of unpaid work, etc.. The average GDP growth rate was moderate (4.5\%) from 1981 to 1991, then dropped, averaging only 0.8\% from 1992 to $2012 .^{17}$

We may add the following points. The introduction of housework-related electronic appliances, such as refrigerators, microwaves, washing machines, and vacuum cleaners, has saved time. Using market services supplied at low cost has also saved time. These are signs of rationalization of housekeeping, giving us more freedom of choice in time use. In Japan, however, the following should be noted: (1) The hours of unpaid work done by women have been trending slightly downward. This slow decrease may be caused by an increase in lower priority time use; (2) Men's unpaid work hours show small increases, but the initial numbers were so low that the percentage increase is relatively great; and (3) There is a large wage rate difference between men and women. These combined effects ${ }^{18}$ have also lifted the household production to GDP ratio.

The Japanese household production to GDP ratio was not high compared with that of the countries cited in the Introduction. The percentage depends on changes in population structure, GDP growth rates, the unpaid work hours done by men and women, and hourly wage rates and differences between men's and women's wages. It may also reflect social customs and systems. This needs further examination.

\section{Conclusion}

We examined households in three stages: young couples with 1.36 children, middle-aged couples with 1.87 children, and older couples with 2.01 children. We compared household incomes based on the current GDP concept and a broader view that includes the unpaid household production by spouses and HOHs. We also estimated annual work hours for men and women that include unpaid work.

\footnotetext{
${ }^{17}$ See NIPSSR (2015), Table 4-1 for the baby boom generation; CAO of GoJ (2013) (Japanese edition) for long-term statistics for the average GDP growth rate.

${ }^{18}$ Per capita women's work hours decreased slightly from 1,471 (1986) to 1,381 (2011) (93.9\%) in 25 years. Men's work hours increased greatly from 106 (1981) to 284 (2011) (268\%) in 30 years. However, the number of yearly hours worked by men was much smaller than women's hours (106 to 1,467 in 1981) (DNA, 2013, Fig-Table 11). Men's unpaid hours of work were one-fifth of women's hours in 2011 (DNA, 2013, Fig-Table 2). Limiting to couples with a child or children, child-rearing (childcare) hours for both women and men increased during the years from 1981 to 2011. As a result, for non-working women, unpaid work hours remained more or less at the same level; for working women, their unpaid work hours increased (SB of MIAC, 2013, Vol. 7 "Summary Results and Analyses", Table 5-6 and Fig. 5-5).
} 
Our first result is that, by including household production, income differences converge significantly. This influence is greater in Stage I (young couples) than in Stage II (middle-aged couples) and Stage III (older couples) (see Table 2). We have an average for the value of unpaid work done by working spouses but we need to obtain better estimates that break this into full- and part-time workers. There are no recent suitable data available for this decomposition, so we used data based on 1990 time-use surveys.

Secondly, women work longer hours than men do in all stages. Women working full-time in all stages, those working part-time in Stages I and II, and non-working homemakers in Stage I work more than three thousand hours per year. However, women's total incomes, including the value of unpaid work, are low, reflecting great wage differences between sexes and between full- and part-time workers (see Tables 3 and 4). This means that Japanese women are overloaded, particularly working women.

Thirdly, taking this approach, we arrive at a different view of income distribution and poverty rates. The results show improved income distribution (an equalizing effect) and decreased poverty percentages. Case $\mathrm{C}$ (couple with non-working female spouse) in all stages has relatively low market incomes but the income gaps between cases A (both $\mathrm{HOH}$ and spouse working full-time) and $\mathrm{C}$ become much smaller when household production is included (see Table 2).

This analysis may have some weaknesses. Our estimates are mostly based on recent surveys. For lack of proper data, however, we used alternative data and applied simple assumptions to decompose the value of unpaid work by working spouses into full- and part-time estimates. However, we do not expect these treatments to distort the outcomes to a large degree.

Finally, Japanese household production to GDP ratios have increased since the 1981 estimate of the value of unpaid work, though these ratios are not high compared with those of some other countries. This can be partly explained by the following facts: (1) Japan's shifting population structure (the baby boom effect) has contributed to an increase in the value of unpaid work, and low GDP growth rates since 1992 have stagnated the growth of the GDP denominator; (2) With increased housework efficiency, women seem to choose going outside their homes to work or pursue lower priority activities such as housework and leisure rather than doing nothing; and (3) Reflecting the high wage rate difference between men and women, increases in unpaid work done by men contribute to the relatively high values.

What will be the policy implications of this research?

(1) A broad view of household production reveals a different perspective on inequalities of income distribution and poverty rates; (2) The results of estimate present some important factors in the discussion on such as low birthrate, work/life balance, and living standards; and (3) The household production replaced as an economy develops and more women go to work may increase income under the GDP concept. We need to quantify this increase, since we have not dealt with this matter in this paper.

\section{References}

21 Seiki Shokugyo Zaidan. (2012). Analysis on women labour 2011. Tokyo: 21 Seiki Shokugyo Zaidan. (in Japanese)

Cabinet Office, Government of Japan [CAO of GoJ]. (2013). Annual report on the Japanese economy and public finance 2013 (English edition available). Cabinet Office, Government of Japan. Tokyo: Nikkei Insatsu Co. Ltd. (in Japanese)

Central Labour Relations Commission. (2014). Comprehensive survey on wages circumstances, etc. 2012. Retrieved from http://www.mhlw.go.jp/churoi/chousei/chingin/12/index3.html (in Japanese)

Department of National Accounts [DNA]. (2013). Money value of housekeeping activities: Re-estimate on 2011 Data (pp. 1-16 and Figure-Table pp. 1-21). Economic and Social Research Institute (ESRI), Cabinet Office (CAO). Retrieved from http://www.esri.cao.go.jp/jp/sna/sonota/satellite/roudou/roudou_top.html (in Japanese) 
Department of Public Opinion Survey [DPOS]. (1992). Time use of Japanese 1990. Nippon Hoso Kyokai (NHK; Japan Broadcasting Corporation). Tokyo: NHK Publication. (in Japanese)

Hamada, K. (2006). Unpaid labour and income distribution: Money value of unpaid labour by income group. Japanese Journal of Research on Household Economics (The Institute of Research on Household Economics), 69, 59-69. (in Japanese)

Hill, T. P. (1979). Do it yourself and GDP. Review of Income and Wealth, 25(1), 31-39.

Iyoda, M. (2013). An aging society with a declining birthrate: Japan (moving toward a sustainable society). Research Institute (St. Andrew's University, Osaka) Working Paper Series, No. 40, pp. 1-19.

Iyoda, M. (2014). An aging society with a declining birthrate: Japan (moving toward a sustainable society). Journal of Economic Policy Studies, 11(2), 35-38. (Condensed version of Iyoda (2013))

National Institute of Population and Social Security Research [NIPSSR]. (2015). Trends of population 2015: Japan and world. Tokyo: Kosei Rodo Tokei Kyokai. (in Japanese)

Organization for Economic Cooperation and Development [OECD]. StatExtracts. Retrieved from http://stats.oecd.org/Index.aspx?DataSetCode=SNA_Table4\#

Statistics and Information Department of the Minister's Secretariat, Ministry of Health, Labour and Welfare [SID of MS, MHLW]. (2013). Annual report on the monthly labour survey 2011. Tokyo: Romu Gyosei Co. Ltd..

Statistics and Information Department of the Ministry of Health, Labour and Welfare [SID of MHLW]. (2013). Basic survey on wage structure 2011 (Vol. 1-5). Tokyo: Rodo-Horei Kyokai. Retrieved from www.e-stat.go.jp/SGI/estat/ (in Japanese)

Statistics Bureau of the Ministry of Internal Affairs and Communications [SB of MIAC]. (2013). 2011 survey on time use and leisure activities (Vol. 1-8). Tokyo: National Statistics Centre.

Statistics Bureau, Ministry of Public Management, Home Affairs, Post and Telecommunications [SB of MPHPT]. (2001). National survey of family income and expenditure 1999. Tokyo: Japan Statistical Association.

Statistics Bureau, Ministry of Public Management, Home Affairs, Post and Telecommunications [SB of MPHPT]. (2002). Annual report on the family income and expenditure survey 2001. Tokyo: Japan Statistical Association.

Stiglitz, J., Sen, A., \& Fitoussi, J. P. (Eds.). (2009). Report by the Commission on the Measurement of Economic Performance and Social Progress. Retrieved from http://stiglitz-sen-fitoussi.fr/en/index.htm

Talberth, J., Cobb, C., \& Slattery, N. (2007). The genuine progress indicator 2006: A tool for sustainable development. Oakland, CA: Redefining Progress.

\section{Appendix A}

\section{Decomposition of Unpaid Value of Working Spouses into Full- and Part-Time Workers}

NHK (1992), Fig-Table 12 includes married women's time-use for full-time, part-time, and non-working (doing housework) women for both weekdays and weekends in 1990. Fig-Table 13 shows only weekday time-use for 10-year age brackets, and includes no weekend data.

Step 1. Calculate unpaid work hours, totaling weekday and full week hours for spouse's work type (NHK, 1992, Fig-Table 12).

Table A1

Unpaid Work Hours by Woman's Work Type (Units: Hours/Week)

\begin{tabular}{lll}
\hline Hours worked & Weekdays & Full week \\
\hline Non-working & 37.33 & 51.03 \\
Full-time & 17.00 & 26.70 \\
Part-time & 23.92 & 34.97 \\
\hline
\end{tabular}

Step 2. Using the results from Step 1, we calculate the percentage ratios of weekdays and full-week hours to those of a non-working homemaker for full- and part-time working women, and obtain the weekday and full week differences as percentages.

Table A2

Ratios of Unpaid Work Hours: Working Women to Non-working Women

\begin{tabular}{llllll}
\hline Ratio of hours worked & Weekdays (a) & Full week (b) & Difference (b)-(a) \\
\hline Full-time/Non-working & $(17.00 / 37.33)$ & $45.5(\%)$ & $(26.70 / 51.03)$ & $52.3(\%)$ & 6.8 \\
Part-time/Non-working & $(23.92 / 37.33)$ & $64.1(\%)$ & $(34.97 / 51.03)$ & $68.5(\%)$ & 4.4 \\
\hline
\end{tabular}


Step 3. Calculate unpaid work hour ratios (as percentages) by age bracket (NHK, 1992, Fig-Table 13). Combine the results (differences) with those from Table A2.

Table A3

Ratios of Unpaid Work Hours by Working Women to Non-working Women by Age (Units: \%)

\begin{tabular}{|c|c|c|c|}
\hline & \multicolumn{3}{|c|}{$\operatorname{Age}^{1)}$} \\
\hline & 30s (weekdays + dif.) & 40s (weekdays + dif.) & 50s (weekdays + dif.) \\
\hline \multicolumn{4}{|l|}{ Unpaid work hour ratio } \\
\hline Full-time/Non-working & $43.0+6.8=49.8$ & $45.9+6.8=52.7$ & $44.6+6.8=51.4$ \\
\hline Part-time/Non-working & $59.6+4.4=64.0$ & $65.8+4.4=70.2$ & $61.6+4.4=66.0$ \\
\hline \multicolumn{4}{|l|}{ Full-time/Part-time } \\
\hline Weekdays & $(43.0 / 59.6) \quad 72.1 \%$ & $(45.9 / 65.8) \quad 69.8 \%$ & $(44.6 / 61.6) \quad 72.4 \%$ \\
\hline Full week & (49.8/64.0) $77.8 \%$ & (52.7/70.2) $75.1 \%$ & $(51.4 / 66.0) \quad 77.9 \%$ \\
\hline
\end{tabular}

Note. ${ }^{1)}$ : For data by age bracket, we have 10 -year brackets (30s, 40s, and 50s) and the data are limited to weekdays.

Step 4. Using the results, we calculate unpaid value of work and unpaid work hours. Tables A4 and A5 show the unpaid value of work and unpaid work hours by work type.

Table A4

Unpaid Value of Work by Work Type and Age (Units: Thousand Yen)

\begin{tabular}{|c|c|c|c|c|c|c|}
\hline \multirow{2}{*}{ Unpaid value of work } & \multicolumn{6}{|c|}{ Stage } \\
\hline & Stage I (30-34) & & Stage II (40-44) & & Stage III (50-54) & \\
\hline Full-time & $(4,340 \times 0.498)$ & 2,161 & $(4,321 \times 0.527)$ & 2,277 & $(3,629 \times 0.514)$ & 1,865 \\
\hline Part-time & $(4,340 \times 0.640)$ & 2,778 & $(4,321 \times 0.702)$ & 3,033 & $(3,629 \times 0.660)$ & 2,395 \\
\hline$x=$ full-time fraction (in working woman) & $49.8 \%$ & & $46.4 \%$ & & $37.9 \%$ & \\
\hline$(1-x)=$ part-time fraction & $2,161 x+2,778($ & $=2$ & $2,277 x+3,033$ & $x)=2$, & $1,865 x+2,395$ & )$=$ \\
\hline
\end{tabular}

Notes. Full- and part-time values of work are obtained by [value of non-working woman’s work $\times$ full-time/non-working unpaid work hour ratio] and [value of non-working woman's work $\times$ part-time/non-working unpaid work hour ratio], respectively. Source: See Table 1.

Table A5

Unpaid Work Hours by Work Type (Units: Hours/Year)

\begin{tabular}{|c|c|c|c|c|c|c|}
\hline \multirow{2}{*}{ Unpaid work hours } & \multicolumn{6}{|c|}{ Stage } \\
\hline & Stage I (30-34) & & Stage II (40-44) & & Stage III (50-54) & \\
\hline Full-time & $(3,035 \times 0.498)$ & 1,511 & $(2,772 \times 0.527)$ & 1,461 & $(2,362 \times 0.514)$ & 1,214 \\
\hline Part-time & $(3,035 \times 0.640)$ & 1,942 & $(2,772 \times 0.702)$ & 1,946 & $(2,362 \times 0.660)$ & 1,559 \\
\hline
\end{tabular}

Notes. Full- and part-time work hours are obtained by [hours of non-working woman's work $\times$ full-time/non-working unpaid work hour ratio] and [hours of non-working woman's work $\times$ part-time/non-working unpaid work hour ratio], respectively. Source: See Table 5 for unpaid work hours of non-working women.

\section{Appendix B}

This appendix examines the possibility of correspondence between the two classifications ((1) stages by age bracket and (2) child-rearing stages by youngest child), both of which are applied to married couples.

Table B1 shows the percentage distribution of working and non-working married women, and unpaid work hours of married women by age and by youngest child. By observation, there do not seem to be significant differences between the second and third stages, but there exists a significant difference between Stage I and the first child-rearing stage of the youngest child (pre-school).

There are categorical differences between these classifications. Classification (1) includes married couples with and without a child (children), and has clear age bands. Classification (2) includes only married couples with a child (children) and has wide age 
dispersions. We adopt the opportunity cost method in this paper, using wage rates that vary by sex and age bracket. According to the age brackets, we obtain paid income and wage rates, but this becomes difficult under wide age dispersions. Therefore, estimating household income becomes difficult in this case. As a result, child-rearing stages by youngest child (2) cannot be a proxy variable of (1) household stage by female spouse's age bracket. This does not mean to deny the value of analysis based on child-rearing stage by youngest child. Such analysis may contribute significant information. What we mean is that (2) is not suited to our present approach.

Table B1

Percentages of Working and Non-working and Unpaid Work Hours by Age and by Youngest Child (Married Women)

\begin{tabular}{|c|c|c|c|c|c|c|}
\hline \multirow{2}{*}{ Stages } & \multicolumn{3}{|c|}{ Number of samples } & \multicolumn{3}{|c|}{ Unpaid work hours ${ }^{1)}$} \\
\hline & Total & Working (\%) & Non-w (\%) & Working & Non-w & W/Non-w (\%) \\
\hline \multicolumn{7}{|l|}{ (1) Age } \\
\hline I: $30-34$ & 6,470 & 59.5 & 40.5 & $1,734(285)$ & $3,103(510)$ & 57.0 \\
\hline II: $40-44$ & 10,609 & 72.3 & 27.7 & $1,716(282)$ & $2,768(455)$ & 62.0 \\
\hline III: 50-54 & 10,936 & 76.2 & 23.8 & $1,424(234)$ & $2,373(390)$ & 60.0 \\
\hline \multicolumn{7}{|l|}{ (2) Youngest child } \\
\hline Pre-school & 14,008 & 52.7 & 47.3 & $2,190(360)$ & 3,242 (533) & 67.5 \\
\hline Primary school & 9,660 & 74.1 & 25.9 & $1,770(291)$ & $2,677(440)$ & 66.1 \\
\hline J\&S high schools ${ }^{2)}$ & 8,775 & 79.9 & 20.1 & $1,679(276)$ & $2,583(425)$ & 65.0 \\
\hline
\end{tabular}

Notes. Non-w and W denote non-working and working, respectively. ${ }^{1)}$ : Following the government example (treatment), traveling (for shopping, etc.) is not included as unpaid work (equivalent to commuting time not being included in work hours). Annual hours (weekly average minutes in parentheses); and ${ }^{2)}$ : J\&S high schools denote junior and senior high schools. Sources: SB of MIAC (2013), Vol. 1, Table 4 for (1); and Vol. 1, Table 3 for (2).

Table B2 shows unpaid work hours by work type. ${ }^{19}$ By observation, we can find similar characteristics to those of Table B1. This suggests that the first stage by female spouse's age (30-34) (Stage I) does not seem to correspond to the first child-rearing stage by youngest child (pre-school). Differences in the second and the third stages are relatively moderate.

Table B2

Unpaid Annual Work Hours by Work Type (2011) (Units: Hours/Year or \%)

\begin{tabular}{llcc}
\hline \multirow{2}{*}{ Household stage classification } & \multicolumn{3}{c}{ Unpaid work hours } \\
\cline { 2 - 4 } & Household Stage 1 & Household Stage 2 & Household Stage 3 \\
\hline (1) Stage by age & Stage I (30-34) & Stage II (40-44) & Stage III (50-54) \\
\hline Working (Men) & 367 & 246 & 198 \\
Working (Women) & 1,728 & 1,720 & 1,428 \\
Non-working & 3,035 & 2,772 & 2,362 \\
No-child households (\%) & $(22.1)$ & $(12.2)$ & $(19.5)$ \\
\hline (2) Child-rearing by youngest child & Pre-school & Primary school & J\&S high schools ${ }^{2)}$ \\
\hline Working (Men) & 420 & 231 & 180 \\
Working (Women) & 2,190 & 1,770 & 1,670 \\
Non-working & 3,242 & 2,677 & 2,583 \\
\hline
\end{tabular}

Notes. ${ }^{1)}$ : No-child households include both those of couples without children and those of couples whose child/children do not live with them; and ${ }^{2)}$ : J\&S high schools denote junior and senior high schools. Sources: DNA (2013), Figure-Table 14, for (1); SB of MIAC (2013), Vol. 1, Table 3, for (2) (obtained and calculated). No-child households (\%) are calculated as "the percentage of no-child household women in the married women total” (NIPSSR, 2015, Tables 6-22 and 7-28).

${ }_{19}$ Data for five-year brackets, e.g., (30-34), include no-child households. Eliminating no-child households, unpaid work hours will increase, in particular in the first stage. Eliminated data are available only for 10-year brackets, e.g., (30-39). For the spouses aged 30-39 without children, the unpaid work hours are $40.1 \%$ of those of the working and $62.5 \%$ of those of the non-working spouses with a child (children) (calculated from SB of MIAC, 2013, Vol. 1, Table 9). The high percentages of no-child households in the third stage are perhaps due to the fact that some children either leave home for education or become independent of their parents. 